\title{
PERANCANGAN SISTEM INFORMASI ADMINISTRASI KEPENDUDUKAN DESA BERBASIS WEBSITE PADA DESA WINONG
}

\author{
Akhmad Syukron \\ Program Studi Sistem Informasi \\ Universitas Bina Sarana Informatika Kampus Kabupaten Banyumas \\ akhmad.khy@bsi.ac.id
}

\begin{abstract}
Population administration is a series of activities for structuring and controlling documents and population data as well as utilizing the results for public services and the development of other sectors. Winong village as one of the government agencies has an important role, namely as a manager of population data at the village level. Current management of population data in Winong Village still does not maximize the use of information technology for its management, so there are still some shortcomings and constraints faced. Such as there are still population data, difficulties in finding data, and making population reports. So that services to the community and work from the village apparatus are less effective and efficient. Therefore we need a computerized information system that can be used to manage the data. The method used for the design of population administration systems is the prototyping method. With the existence of this website-based population administration information system, it can facilitate the management of population data. So that it can materialize in good population administration in the village of Winong.
\end{abstract}

Keywords: Information Systems, Population Administration, System Design

Abstrak : Administrasi kependudukan merupakan rangkaian kegiatan penataan dan penertiban dokumen dan data kependudukan serta pendayagunaan hasilnya untuk pelayanan publik dan pembangunan sektor lain. Desa Winong sebagai salah satu instansi pemerinatahan, memiliki peran yang penting yaitu sebagai pengelola data kependudukan di tingkat desa. Pengelolaan data kependudukan di Desa Winong saat ini masih belum memaksimalkan penggunaan teknologi informasi untuk pengelolaannya, sehingga masih terdapat beberapa kekurangan dan kendala yang dihadapi. Seperti masih terdapat kerangkapan data kependudukan, ksulitan dalam pencarian data, serta pembuatan laporan kependudukan. Sehingga pelayanan kepada masyarakat serta kerja dari perangkat desa menjadi kurang efektif dan efisien. Oleh karena itu dibutuhkan sebuah sistem informasi terkomputerisasi yang dapat digunakan untuk mengelola data tersebut. Metode yang digunakan untuk perancangan sistem administrasi kependudukan yaitu dengan metode prototyping. Dengan adanya sistem informasi administrasi kependudukan yang berbasiskan website ini, dapat memudahkan pengelolaan data kependudukan. Sehingga dapat terwujud tertib administrasi kependudukan yang baik di desa Winong.

Kata Kunci : Sistem Informasi, Administrasi Kependudukan, Perancangan Sistem

\section{Pendahuluan}

\subsection{Latar Belakang}

Sebagai salah satu instansi pemerintah ditingkat bawah, desa memiliki peran yang penting dalam sebuah pemerintahan. Salah satu peran penting desa yaitu sebagai pengelola data kependudukan seperti pendataan penduduk dalam proses pembuatan KTP kartu keluarga, surat kelahiran, surat kematian dan surat keterangan pindah. Sesuai dengan UU no. 23 Tahun 2006 tentang Administrasi Kependudukan serta PP No. 37 Tahun 2007 tentang Pelaksanaan UU No. 23 Tahun 2006 tentang Administrasi Kependudukan. Tujuan dari administrasi kependudukan yaitu tertib database kependudukan, tertib penerbitan NIK, dan tertib dokumen kependudukan. Oleh karena itu data kependudukan di tingkat desa harus benar-benar di kelola dengan tepat dan akurat sesuai keadaan terkini dari setiap penduduk desa. Sehingga dengan data yang akurat tersebut dapat berguna untuk implementasi kebijakan atau program pemerintah lainnya seperti pendataan statistik, ataupun untuk penentuan daftar pemilih tetap yang dapat digunakan untuk pemilihan umum atau pemilihan kepala daerah. Pada desa Winong pencatatan dan pengoelolaan administrasi kependudukan masih belum menggunakan sistem komputerisasi secara menyeluruh untuk mengelola data tersebut. Dimana data masih dicatat di buku induk kependudukan dan pemnafaatan komputer masih sebatas untuk keperluan surat menyurat . Sehingga masih dijumpai beberapa kendala seperti data hilang atau rusak, ditemukannya data ganda, tidak terintegrasinya data secara menyeluruh serta 
kesulitan dalam melakukan pencarian data dengan cepat, tepat dan akurat. Selain itu perangkat desa juga mengalami kesulitan dalam melakukan pendataan penduduk dan pembuatan laporan bulanan.

Selain itu proses pelayanan surat menyurat untuk adminstrasi kependudukan, saat ini masih melalui beberapa proses yang cukup panjang mulai dari surat pengantar RT, RW dan selanjutnya diteruskan ke desa sebagai syarat administratif. Hal ini tentunya akan memerlukan waktu yang cukup lama, apabila menggunakan cara konvensional yang belum memanfaatkan sistem informasi. Oleh karena itu, untuk meningkatkan kualitas pelayanan kepada masyarakat di desa Winong serta untuk mewujudkan pemerintahan yang tertib administrasi. Maka diperlukan sebuah sistem terkomputerisasi berbasis website, sehingga pelayanan kepada masyarakat dapat lebih efektif dan lebih baik.

\subsection{Rumusan Masalah}

Berdasarkan identifikasi permasalahan yang dihadapi dapat ditemukan beberapa masalah pokok yang dirumuskan sebagai berikut:

1. Sistem administrasi kependudukan yang digunakan di Desa Winong saat ini masih menggunakan cara manual, sedangkan pemanfaatan komputer hanya sebatas untuk pembuatan surat menyurat dan pencatatan data penduduk.

2. Perangkat Desa mengalami kesulitan ketika akan melakukan pendataan penduduk dan pembuatan laporan data kependudukan. Seperti laporan jumlah penduduk lahir, mati, pindah dan juga data pemilih tetap.

3. Perangkat Desa mengalami kesulitan dalam pencarian data secara cepat, tepat dan akurat.

4. Masih sering ditemukannya data penduduk ganda dan ketidaksesuaian data.

5. Kurang efektif dan efisiennya sistem yang digunakan saat ini.

\subsection{Tujuan Penelitan}

Menghasilkan sebuah sistem informasi terpadu untuk mengelola administrasi kependudukan yang terkomputerisasi yang efektif dan akurat untuk memudahkan kerja perangkat desa dan juga untuk meningkatkan pelayanan kepada masyarakat desa Winong.

\section{Tinjauan pustaka \\ 2.1 Sistem Informasi}

Menurut (Hutahaean, 2015:13) mengemukakan bahwa, "Sistem informasi adalah suatu sistem di dalam suatu organisasi yang mempertemukan kebutuhan pengelolaan transaksi harian, mendukung operasi, bersifat manajerial, dan kegiatan startegi dari suatu organisasi dan menyediakan pihak luar tertentu dengan laporan-laporan yang dibutuhkan".

\subsection{Administrasi Kependudukan}

Administrasi kependudukan adalah rangkaian kegiatan penataan dan penertiban dalam penerbitan dokumen dan data kependudukan melalui pendaftaran penduduk, pencatatan sipil dan pengelolaan informasi penduduk serta pendayagunaan hasilnya untuk pelayanan publik, pemerintahan dan pembangunan.

(http://www.dukcapil.kalbarprov.go.id)

Sedangkan substansi dari adminduk yaitu berupa pencatatan sipil dan pendaftaran kependudukan. Pencatatan sipil berupa pencatatan kelahiran, lahir mati, perkawinan, pembatalan perkawinan, perceraian, pembatalan perceraian, kematian, pengangkatan pengesahan dan pengakuan anak, perubahan nama dan perubahan status kewarganegaraan, peristiwa penting dan pelaporan penduduk yang tidak bisa melapor sendiri.

\subsection{Website}

Menurut Hidayat (2010:1) Website adalah kumpulan halaman-halaman yang digunakan untuk menampilkan informasi teks, gambar, diam atau gerak, animasi, suara, dan atau gabungan dari semuanya, baik yang bersifat statis maupun dinamis yang membentuk satu rangkaian bangunan yang saling terkait, yang masing-masing dihubungkan dengan jaringan -jaringan halaman. Jenis-jenis web berdasarkan sifat atau stylenya.

1. website dinamis, merupakan sebuah website yang menyediakan konten atau isi yang selalu berubah -ubah setiap saat. Bahasa pemrograman yang digunakan antara lain php,asp, .net dan pemanfatakan databse mysql atau mssql.

2. website statis, merupakan website yang kontennya jarang diubah.bahasa pemrograman yang digunakan adalah $\mathrm{html}$ dan belum memanfaatkan database.

\subsection{Basis data (database)}

Menurut Wahana Komputer (2015) Basis Data adalah kumpulan informasi yang 
disimpan di dalam komputer secara sistematik sehingga dapat diperiksa menggunakan suatu program komputer untuk memperoleh informasi dari basis data tersebut. Komponen utama yang terdapat pada sebuah sistem basis data yaitu hardware,sistem operasi, basis data, sistem pengelola basis data, pemakaidan aplikasi lain yang bersifat opsional. (Fathansyah,2018).

MySQL merupakan sebuah implementasi dari sistem manajemen basis data relasional (RDBMS) yang didistribusikan secara gratis dibawah lisensi GPL (General Public License). Wahana Komputer (2015). MySQL merupakan penyimpanan data yang fleksibel dan cepat aksesnya sangat dibutuhkan dalam sebuah website yang interaktif dan dinamis.

\subsection{UML (Unifield Modelling Language)}

Menurut (Sukamto dan Shalahuddin, 2018:133) mengemukakan bahwa, "UML (Unifield Modelling Language) adalah salah satu standar bahasa yang banyak digunakan di dunia industri untuk mendefinisikan requirement, membuat analisis dan desain, serta menggambarkan arsitektur dalam pemrograman berbasis objek"

1. Use case diagram

Use case diagram merupakan pemodelan untuk kelakuan (behavior) sistem yang akan dibuat". Use case digunakan untuk mengetahui fungsi apa saja yang ada di dalam sebuah sistem informasi dan siapa saja yang berhak menggunakan fungsifungsi itu. Adapun syarat penamaan pada use case adalah nama didefinisikan semudah mungkin dan dapat dipahami. Terdapat dua hal utama pada use case yaitu pendefinisian aktor dan use case.( Sukamto dan Shalahuddin, 2018:133).

2. Activity diagram

Diagram aktivitas atau activity diagram menggambarkan workflow (aliran kerja) atau aktivitas dari sebuah sistem atau proses bisnis atau menu yang ada pada perangkat lunak". Diagram aktivitas menggambarkan aktivitas sistem bukan apa yang dilakukan aktor, jadi aktivitas yang dapat dilakukan oleh sistem.

3. Class diagram

Sukamto dan Shalahuddin mengemukakan bahwa, "Diagram kelas atau class diagram menggambarkan struktur sistem dari segi pendefinisian kelas-kelas yang akan dibuat untuk membangun sistem..

\section{Sequence diagram}

Sukamto \& Shalahuddin mengemukakan bahwa, "Diagram sekuen mnggambarkan kelakuan objek pada use case dengan mendeskripsikan waktu hidup objek dan message yang dikirimkan dan diterima antar objek.

\subsection{ERD}

Menurut (Andriani dan Purnama, 2019) mengemukakan bahwa, "Entity Relationship Diagram atau biasa disebut dengan diagram ER merupakan sebuah penggambaran grafis untuk menggambarkan desain secara konseptual dari database yang akan dibangun".

Model Entity Relationship digunakan untuk mentransformasikan data-data yang ada didunia nyata kedalam bentuk notasi-notasi sebagai perangkat konseptual menjadi diagram data yang dikenal dengan diagram Entity-Relationship. (Maniah \& Hamidin, 2017).

2.7.Model Pengembangan Sistem Prototype

Ogedebe dalam (Purnomo,2017) mengemukakan bahwa Prototype merupakan suatu metode pengembangan perangat lunak, yang berupa model fisik kerja sistem dan berfungsi sebagai versi awal dari sistem.

Prototyping bertujuan untuk mengumpulkan informasi tertentu mengenai kebutuhan-kebutuhan informasi pengguna secara cepat. Sehingga pengguna dapat berinteraksi dengan model prototype yang dikembangkan. Prototype tersebut nantinya akan dievaluasi oleh pelanggan/pemakai dan dipakai untuk menyaring kebutuhan pengembangan perangkat lunak. Keterlibatan pengguna secara penuh ketika prototype terbentuk akan menguntungkan seluruh pihak yang terlibat, bagi pimpinan, pengguna sendiri serta pengembang sistem.

\section{Metode Penelitian}

3.1. Metode Pengembangan Perangkat Lunak Pada penelitian ini metode pengembangan perangkat lunak yang digunakan yaitu, metode Prototype. Pada metode ini tahapan pengembangan dimulai dari mendengarkan pelanggan, membangun , memperbaiki Mock up dan pelanggan melihat, menguji Mock up. 


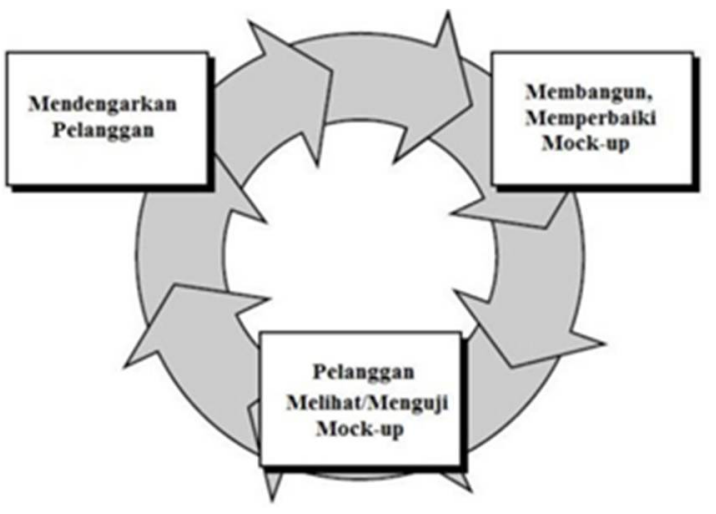

Sumber : (Novita \& Andriani, 2019)

Gambar 1. Metode Prototype

3.2. Metode Pengumpulan data

a) Observasi

Penulis melakukan pengamatan pengamatan langsung terhadap kegiatan yang berhubungan dengan masalah yang diambil. Hasil dari pengamatan tersebut langsung dicatat oleh penulis dan dari kegiatan observasi dapat diketahui kesalahan atau proses dan kegiatan tersebut.

b) Wawancara

Untuk mendapatkan informasi secara lengkap maka penulis melakukan suatu metode suatu tanya jawab dengan karyawan mengenai semua kegiatan yang berhubungan dengan rawat jalan pasien di Puskesmas Winong.

c) Studi Pustaka

Selain melakukan kegiatan diatas penulis juga melakukan studi kepustakaan melalui literatur-literatur atau referensi-referensi yang ada di perpustakaan.

\section{Hasil dan Pembahasan}

\subsection{Analisa Sistem Administrasi Kependudukan}

Desa Winong sebagai pemerintahan di tingkat desa bertugas melakukan pencatatan peristiwa kependudukan dan peristiwa penting di desa. Dalam melakukan pencatatan data kependudukan dimulai dari penduduk yang mengajukan permohonan pembuatan KTP, KK atau pembuatan surat keterangan, baik surat keterangan lahir, keterangan mati, ataupun keterangan pindah. Dengan menyerahkan persyaratan yang diperlukan dan mengisi formulir yang telah disediakan kepada perangkat desa. Perangkat desa akan melakukan verifikasi dan validasi data kependudukan, Jika data salah maka formulir surat keterangan dikembalikan kepada penduduk untuk diperbaiki. jika data benar formulir surat keterangan diserahkan kepada kepala desa untuk ditanda tangani. Kemudian Perangkat desa melakukan pencatatan dalam buku induk peristiwa kependudukan dan peristiwa penting. Setelah itu perangkat desa menyerahkan Formulir kepada pihak kecamatan.

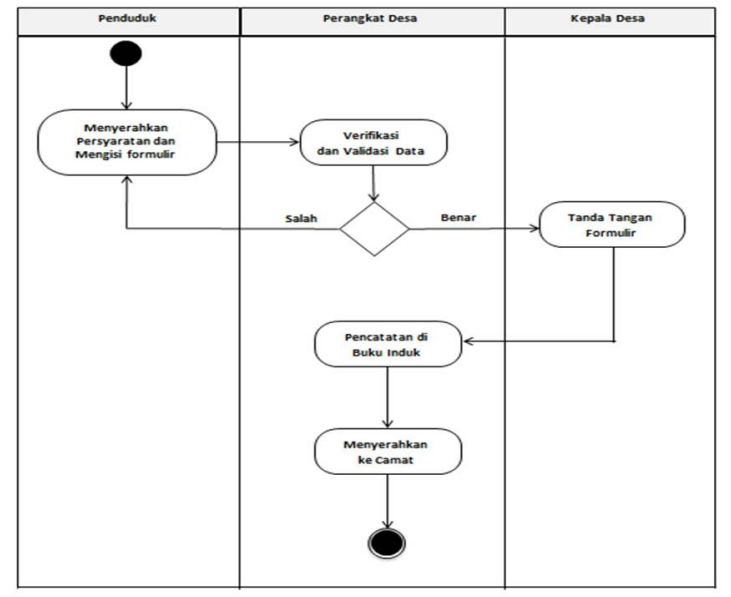

Sumber : Hasil Penelitian 2019

Gambar 2. Activity Diagram Administrasi Kependudukan Desa

\subsection{Analisa Kebutuhan Sistem}

Sistem informasi administrasi kependudukan desa Winong merupakan sebuah sistem informasi yang berbasiskan website yang berfungsi sebagai pengganti dari peran buku induk yang digunakan di desa untuk pencatatan peristiwa kependudukan dan peristiwa penting lainnya. Sistem ini akan menyimpan data-data kependudukan ke dalam database berdasarkan data-data yang diinputkan oleh pengguna melalui form input yang tersedia. Sistem informasi administrasi kependudukan desa Winong terbagi menjadi 2 yaitu halaman untuk administrator sistem yang terdiri dari RT, RW, perangkat desa, kepala desa dan juga halaman user yang digunakan oleh penduduk.

\subsection{Diagram Usecase Sistem Usulan}

Fungsionalitas sistem usulan, digambarkan bahwa aktor dibagi menjadi 5 yaitu penduduk, RT, RW, Perangkat desa, dan kepala desa. Masing-masing aktor memiliki hak akses yang berbeda-beda. Melalui sistem administrasi kependudukan ini penduduk dapat mengajukan permohonan data kepdndudukan seperti permohonan pembuatan KTP, permohonan KK, Permohonan surat pindah, 
permohonan keterangan kelahiran, dan juga permohonan keterangan kematian. Sedangkan RT dan RW dapat menerima notifikasi dan melihat surat permohonan kependudukan. Kemudian akan melakukan verifikasi permohonan dengan mengecek apakah data yang disi dan dokumen persyaratan sudah lengkap.

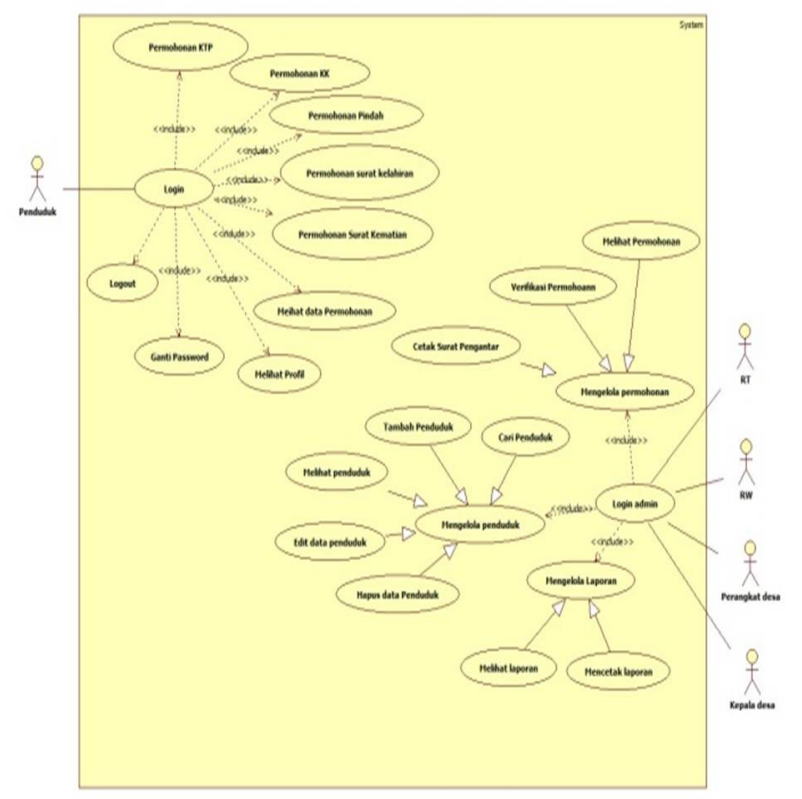

Sumber : Hasil Penelitian 2019

Gambar 3. Use case diagram Administrasi Kependudukan

\subsection{Diagram Activity Sistem Usulan}



Sumber : Hasil Penelitian 2019

Gambar 4. Activity Diagram Usulan

Administrasi Kependudukan

\subsection{Database}

1. Entity Relationship Diagram (ERD)
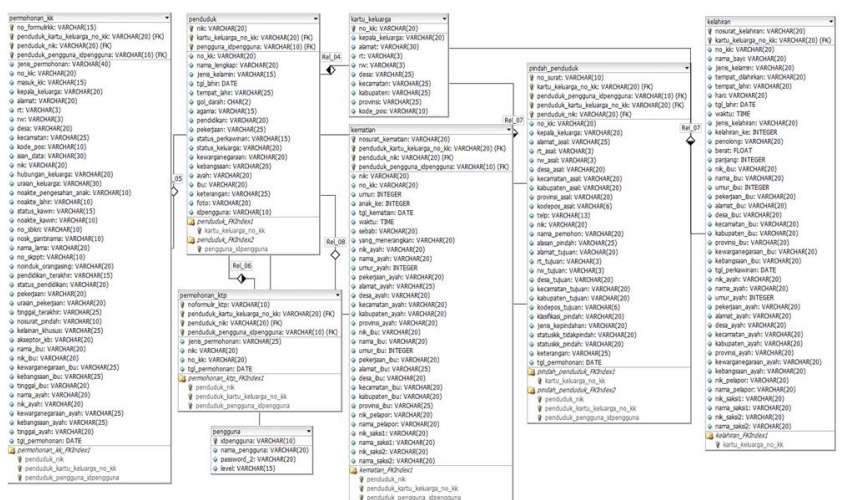

Sumber : Hasil Penelitian 2019

Gambar 5.

ERD Sistem Informasi Administrasi Kependudukan

\subsection{Rancangan Tampilan}

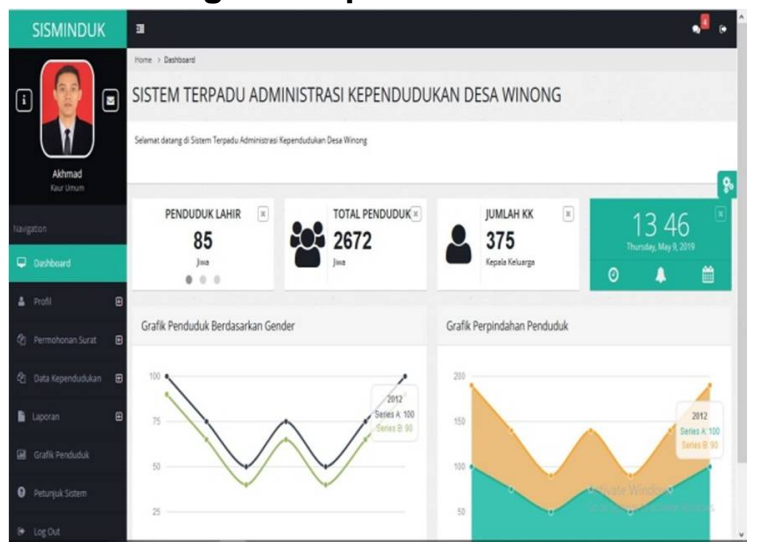

Sumber : Hasil Penelitian 2019

Gambar 6. Halaman Utama sistem Administrasi Kependudukan 


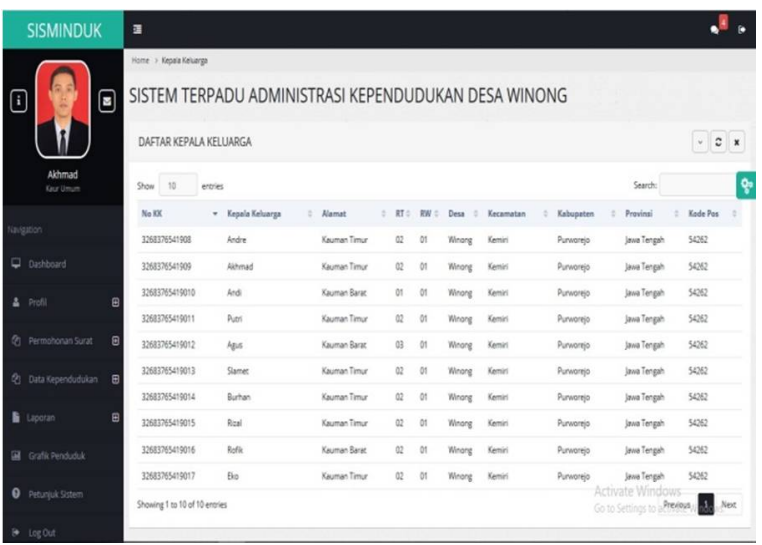

Sumber : Hasil Penelitian 2019

Gambar 7. Halaman Daftar Kepala Keluarga

\section{Kesimpulan Dan Saran}

Berdasarkan analisa dan pembahasan diatas, maka dapat diambil kesimpulan sebagai berikut:

1. Dengan sistem administrasi kependudukan berbasis website, dapat memudahkan penduduk dalam mengurus permohonan administrasi Kependudukan

2. Dapat memudahkan perangkat desa dalam mengelola dan membuat laporan data kependudukan

3. Dapat meningkatkan efektivitas dan efisiensi dalam hal pelayanan terhadap masyarakat desa, sehngga dapat terciptanya tertib administrasi kependudukan.

Untuk memperbaiki sistem usulan di masa yang akan datang, peneliti memberikan saran untuk penelitian berikutnya rancangan sistem ini dapat dikembangkan lagi menjadi lebih luas dengan menyinkronkan data dari pemerintahan diatasnya, seperti Kecamatan dan kabupaten. Sehingga data kependudukan dapat digunakan secara bersama-sama.

\section{DAFTAR PUSTAKA}

Andriani, A., \& Purnama, B. E. (2019). Desain Database dengan ERD dan LRS. Yogyakarta: TEKNOSAIN.

Administrator. 2017. Tentang Administrasi Kependudukan.

https://dukcapil.kalbarprov.go.id/post/tentan g-administrasi-kependudukan.(1, juli, 2019)

Fathansyah. (2018). Basis Data (Revisi Ket). Bandung: Informatika Bandung.

Hidayat, Rahmat. (2010). Cara Praktis Membangun Website Grafis Memanfaatkan Layanan Domain dan Hosting gratis. Jakarta : PT. elex media komputindo.

Hutahaean, J. (2015). Konsep Sistem Informasi.Yogyakarta:Deepublish.

Maniah, \& Hamidin, D. (2017). Analisis dan Perancangan SISTEM INFORMASI (Cetakan Pe). Yogyakarta: Deepublish.

Novita, A., \& Andriani, A. (2019). Prototipe E Learning Untuk Pendalaman Dan Evaluasi Materi Pembelajaran Pada Smpn 1 Samigaluh. Jurnal IImu Pengetahuan Dan Teknologi Komputer, 4(2), 211-216. Diambil dari: http://ejournal.nusamandiri.ac.id/index.php/j itk/article/view/299/261

Purnomo, D. Model prototyping pada Pengembangan Sistem Informasi.jurnal Informatika Merdeka Pasuruan. Vol.2 No.2. Agustus 2017.

Sukamto, dan Shalahuddin, M. (2018). Rekayasa Perangkat Lunak (Edisi Revi). Bandung: Informatika Bandung.

Wahana Komputer. (2015). Membangun Sistem Informasi dengan Java Netbeans dan MySQL (Maya, ed.). Yogyakarta: C.V Andi Offset 